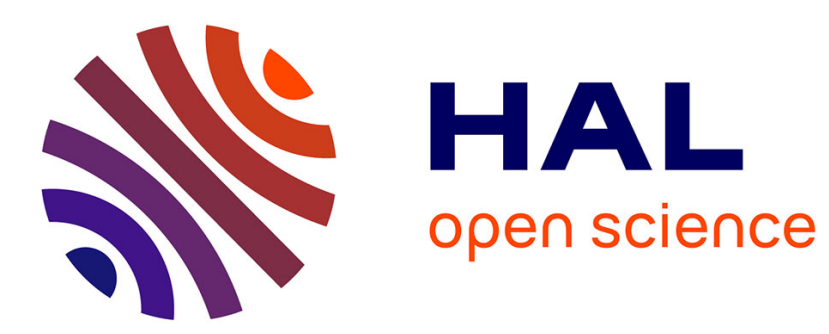

\title{
Nouvelle Biographie, Pulp Nonfiction, and National Crisis: the year in france \\ Joanny Moulin
}

\section{To cite this version:}

Joanny Moulin. Nouvelle Biographie, Pulp Nonfiction, and National Crisis: the year in france. Biography, 2017, 40 (4), pp.588-595. 10.1353/bio.2017.0051 . hal-02105225

\section{HAL Id: hal-02105225 \\ https://hal.science/hal-02105225}

Submitted on 20 Apr 2019

HAL is a multi-disciplinary open access archive for the deposit and dissemination of scientific research documents, whether they are published or not. The documents may come from teaching and research institutions in France or abroad, or from public or private research centers.
L'archive ouverte pluridisciplinaire HAL, est destinée au dépôt et à la diffusion de documents scientifiques de niveau recherche, publiés ou non, émanant des établissements d'enseignement et de recherche français ou étrangers, des laboratoires publics ou privés. 


\title{
NOUVElle bIOGRAPHIE, PULP NONFICTION, AND NATIONAL CRISIS
}

THE YEAR IN FRANCE

\author{
JOANNY MOULIN
}

By a stroke of fate, the summer of 2017 has seen the demise of two famous French biographers, Max Gallo (1931-2017) and Gonzague Saint Bris (19482017). Although they came from radically different social backgrounds, they both stood for a certain idea of biography as a popular literary genre characterized by conservative tendencies and a kitsch style of pop history.

Max Gallo was the son of working-class Italian immigrants who had found in Nice, in southeast France, a shelter against Mussolini's fascism before his father took an active part in the French resistance. Having left school at the age of eleven to earn a living as a factory worker, then as a radio technician, Max went on educating himself as an autodidact. At the time of the Algerian War, in 1956, he was already leaving the Communist Party, and the next year he passed the agrégation to become a professor of history at Lycée Masséna. Then in 1968 he defended a PhD dissertation on Italian fascist propaganda that opened for him the door to a brief academic career as assistant lecturer at the University of Nice. Dabbling in politics and journalism, he became a socialist member of Parliament in 1981, the year when the socialist Union de la Gauche won the presidential election with François Mitterrand: Gallo acquired national notoriety as an official government spokesman. In 1992, he left the Socialist Party to found a center-left divergent current with Jean-Pierre Chevènement, whom he still supported in the 2002 election that saw the defeat of the Socialist Party and the extreme-right leader of the Front National reach the second round of the presidential election, a shocking first since World War II. In 2005, Gallo campaigned for the "No" in the referendum on the European Constitution that brought the build-up of political Europe to a halt. In 2007 he had completed his ideological metamorphosis, 
and spoke publicly in favor of the right-wing candidate Nicolas Sarkozy, adhering with naïve sincerity to the apology for the necessity of the debate on the question of identité nationale. In 2008, Gallo was elected to the Académie française.

This thumbnail life sketch is helpful in understanding the ideological meaning of Gallo's literary commitment, based on the conviction Gallo captured in his La Croix article titled, "La France est dans une crise nationale de longue durée" [France is in an extended period of national crisis]. In an interview to the news magazine Le Point, which claims to be a French equivalent of Time magazine, he declared that, contrary to the US, France is a country where the people are not united by an "attachement religieux" (Gallo, "Il suffit"), going as far as to say that the French Revolution was "un antimodèle qui pèse encore aujourd'hui" [an antimodel that still weighs on us today], a bloody, unfortunate birth of the Nation that Gallo saw as forever exposing it to "l'irruption de la violence et des barbaries" [an eruption of violence and barbarism]. In a 2002 interview, given to the Catholic news magazine La Vie, which republished this text in July 2017 on the occasion of his death, Gallo declared, "La France a besoin de retrouver ses racines chrétiennes" [France needs to rediscover its Christian roots] ("Pourquoi je prie"). He went on to explain that such had been the meaning of his literary work over the years: "essayer de donner une image la plus complète possible de la diversité de notre histoire nationale" [to attempt to give the most complete image possible of the diversity of our national history]. His multivolume historical novels-Les Chrétiens following Bleu Blanc Rouge and Les patriotes, soon to be followed by Morts pour la France - read like prosopographies, or group biographies, of the most obvious great figures of French history. It is a return to a form of popular historiography, implicitly assuming, like Ralph Waldo Emerson, that "there is properly no history; only biography" (15), turning the page on a few decades of structuralism and the Annales School. There is hardly any difference between Gallo's fictions, his histories, and his biographies, all addressing the kind of subjects journalists call marronniers (chestnuts)—Napoléon, De Gaulle, Victor Hugo, Louis XIV, Henri IV, etc.- the last ones he churned out being Henri IV: Un roi français (2016) and Richelieu: La foi dans la France (2017). Gallo's writing career was a long succession of books celebrating great men, symptomatic of a backward-looking mindset that was a sort of Catholic equivalent of Thomas Carlyle's On Heroes and Hero Worship (1841). In a modern historical context in which it is a crucial issue in France, as indeed in other countries of the European community, when and whether the Old World will overcome at last its ancestral division between national identities that, in the eyes of many, bear the guilt of past barbarism and present impotence, Gallo's no doubt well-meaning effort was more simpleminded than well advised. 
Among the common points between Gallo and Gonzague Saint Bris is the mercenary motivation of their writing: both obviously wrote for money, in the modern heritage of a tradition of commercial paraliterature, a form of what Sainte-Beuve used to call la littérature industrielle and that we might call pulp nonfiction, which is strongly reminiscent of the anas, collections of purple patches, anecdotes, and biographical sketches thriving on the fame of historical figures and celebrities. The generic name comes from the Latin suffix -ana: a popular genre since the late eighteenth century, in which some now-forgotten writers used to specialize, like Charles-Yves Cousin d'Avallon (1769-1840), the prolific author of Voltaireana, Bonapartiana, and so many specimens in the same cultural species. Whereas the nobiliary particle "de" in Cousin d'Avallon's name was a sham (he was a very plebeian Monsieur Cousin from Avallon), Gonzague Saint Bris was the cadet son of a family of the papal nobility. Much as d'Avallon once used his fake particle as a commercial brand, Saint Bris exploited his upper-class origin as a fonds de commerce, posing as an expert and an admirer of the noblesse, producing in book form an equivalent of Point de vue, Images du monde: Le journal des princes d'aujourd'bui, a French popular magazine specializing in Almanach de Gotha members. His last book, published posthumously after his sudden death in a car crash in August 2017, sounds like a testament: Aristocrates rebelles. "Ils sont nés avec un nom et des privilèges. Ils ont choisi leur propre destin; la liberté" [They were born with a name and with privileges. They chose their own destiny: liberty], says the front-page blurb. This book is a collection of biographical sketches, twenty-three in some three hundred pages, presenting a selection of aristocrats' lives, from Germaine de Staël to Antoine de Saint Exupéry, from Alphonse de Lamartine to Simone de Beauvoir. Not that Saint Bris made the aristocracy an exclusive specialty: he could rise to the occasion as when, on the death of Michael Jackson, he published Au paradis avec Michael Jackson based on his own encounter and conversations with the pop star, with whom he had spent some time during his 1992 journey in Gabon. Saint Bris was also the tutelary spirit of La Forêt des livres, an annual literary event he had founded in 1995, where writers and other celebrities signed their books and received awards in the country setting of Chanceaux-près-Loire.

Max Gallo revising once more the Carlylean cult of Great Men to perpetuate the sense of belonging to a national community, Gonzague Saint Bris revisiting the tradition of the anas in the spirit of popular magazines: looking back on the careers of these two French biographers as their obituaries hit the news, one is bound to think Catherine Peters was right when she said, "the biographeras-artist is still living in the nineteenth century. It is hard to imagine a nouvelle biographie, analogous to the nouveau roman, in which anonymous characters 
moved through a neutral landscape, living out narrative-free existences" (44). However, such an opinion is not devoid of a mild touch of what C. S. Lewis called "chronological snobbery, the uncritical acceptance of the intellectual climate common to our own age and the assumption that whatever has gone out of date is on that account discredited" (207-08). For, in retrospect, the nouveau roman appears as the very ephemeral curiosity. There is no reason why the novel should be the compulsory paradigm of all writing, and to all intents and purposes contemporary fiction is characterized by a return to the narrative and the individual life story. Moreover, "new biography" had preceded the nouveau roman in the history of literature: this early twentiethcentury school of biography, of which Lytton Strachey and André Maurois were the paragons in Britain and in France respectively, was characterized by the shorter, fiction-like form of "narrative history" and the predominance of the biographer's point of view. In very different ways, there is much of new biography in Gonzague Saint Bris, the histrionic maverick of noblesse oblige, and in Max Gallo, the Quixotic white knight of national history. The importance of the narrative and the widespread though nonexclusive interest in pre-twentieth-century subjects may also be symptomatic of a present when French culture is striving to overcome its poststructuralist period in the academy, while in literature it has definitely turned its back on the blind alley of the nouveau roman.

Remarkably, the Prix Goncourt de la Biographie, after having rewarded Philippe Forest for Aragon in 2016, was awarded in 2017 to Marianne and Claude Schopp for their brainchild, Dumas fils ou l'Anti-Edipe. It is the firstever biography of Alexandre Dumas fils, the author of La Dame aux Camélias, who was even more famous than his father in his own lifetime, although posterity has elected Alexandre Dumas père, the prolific author of Les Trois Mousquetaires among many other historical novels and biographies. Rather than in Gallo's marronniers, we seem to be more interested in forgotten or rebel figures. For instance, Paul Gauguin, the post-impressionist painter, fascinates us precisely because he scandalously rejected stuffy metropolitan values of nineteenth-century France. David Haziot's Gauguin is one of several biographies of the painter that came out in fall 2017, while the biopic of his years in exile by Edouard Deluc, Paul Gauguin, Voyage à Tahiti, where the painter is played by Vincent Cassel, came out in September 2017. A new edition of Noa Noa, Gauguin's autobiographical narrative of his first journey in Tahiti, is published in a pocketbook collection with a preface by Victor Segalen (1878-1919), the eccentric Breton doctor, novelist, poet, ethnographer, sinologist, and archeologist. It is easy to miss the connection with Jean-Luc Coatalem's Mes Pas vont ailleurs: half-novel, half-biography, where Coatelem addresses Segalen, 
his wandering life, and his multifaceted works in a digressive text, constantly transgressing chronology and demonstrating the modernist potentialities of biographical writing in a style reminiscent of A. J. A. Symons's in The Quest for Corvo (1934) and of American biographer David E. Nye's anti-biography of Thomas Edison, The Invented Self (1983). On blogs, modern readers complain that the writing is confusing and boring to read. No doubt that is a sign of the times.

The year 2017 saw a momentous election in France, and there is a clear public feeling that this presidential campaign and its outcome has turned an important page in our roman national, insofar as it has greatly changed the political landscape. Biographical writing in the largest sense of the term has played an important part in this transformation. Gérard Davet and Fabrice Lhomme's "Un président ne devrait pas dire ça . . ." can be viewed as a form of instant life writing, in which President Hollande authorized two journalists to publish his confidences. The book was judged so scandalously incompatible with the dignity and secrecy demanded of the office of the president that it has played an important part in Hollande's decision not to run for a second term. Some observers went as far as to say that it may have been a form of political suicide. In fall 2016, Gallimard had published two posthumous texts by Hollande's role model, François Mitterrand (1916-1996): Journal pour Anne and Lettres à Anne, containing details about the President's half-secret double life with Anne Pingeot, but these were posthumous works. Scarcely had the campaign been launched when, in January 2017, the satirical paper Le Canard enchaîné made revelations about the past life of Hollande's runner up, the Republican François Fillon, that were tantamount to political assassination. On the seasonal market created by the electoral campaign, every candidate was the object of more or less authorized biographical attempts. Standing out from the usual run of the mill, one could notice in particular Francis Métivier's Mythologie des Présidentiables, a collection of five very short e-books - which can certainly not be suspected of mercenary intentions, as the batch cost only five euros - that purported brief sketches of the mythical images that the candidates projected of themselves. Much more substantial, albeit not more expensive in terms of cost per page, Renaud Dely's La Vraie Marine Le Pen: Une bobo chez les fachos undertook a systematic deconstruction of the public image of the woman leader of the extreme-right National Front, who had never been so close to a potential win. One way or another, never more clearly than this year has biography and autobiography been put to use in the run for the presidency. Some biographies of Emmanuel Macron, like Anne Fulda's, or Caroline Derrien and Candice Nedelec's portrait of the future presidential couple, Les Macron, amounted to apologies under a thin 
veneer of critical distance. More remarkably still, Macron himself produced two autobiographical books: Macron par Macron in late 2016 and Révolution in early 2017 that did much to help sell his character to the electorate.

With Max Gallo and Gonzague Saint Bris an outmoded style of biography is dying away in this country, while the genre discreetly plays a central role in the cultural life of the nation. Away from the conventional old chesnuts, Dominique Bona, the most recently elected woman member of the Académie française (2013) has produced a remarkable text, Colette et les siennes, as part of her vindication of the cause of women, while the historian Georgette Elgey has published her autobiography, Toutes fenêtres ouvertes. This self-narrative of a French intellectual resonates with the renewed interest of the academy in égo-histoire - a concept derived by Pierre Nora in 1987 from the notion of "ego-document" coined by Dutch historian Jacques Presser in the mid1950 s - and more particularly the égo-histoires of modern historians, which are the objects of research of the Réseau Historiographie et Épistémologie de l'Histoire funded by the Agence Nationale de la Recherche. On the whole, it seems at times that nearly every new book has some biographical or autobiographical dimension, while in French cinema le biopic flourishes: among many other examples, Michel Hazanavius's latest film, Le Redoutable, a partial biopic of Jean-Luc Godard's married life with Anne Wiazemsky, is anything but a hagiography of "le plus con des Suisses pro-Chinois" [the daftest pro-Chinese Swiss], as a graffiti on a wall of the Sorbonne labeled the Maoist film-maker in 1968. This brief chronicle cannot hope to do justice to the wealth of biographical productions in France this year, but it seems clear that biography in the larger sense has become a center-stage genre in French cultural and intellectual life. Its innovative potential is still inchoate, but the odds are that it will not take the forms of what the last century called modern.

\section{WORKS CITED}

Bona, Dominique. Colette et les siennes. Grasset, 2017.

Carlyle, Thomas. On Heroes and Hero-Worship: The Heroic in History. 1841. Edited by Annie Russell Marble, Macmillan, 1905.

Carnet du réseau historiographie et épistémologie de l'histoire. N.d., https://crheh.hypotheses. org/tag/ego-histoire. Accessed 28 Sept. 2017.

Cousin d'Avallon, Charles-Yves. Voltairiana, ou Recueil des bons mots, plaisanteries, pensées ingénieuses et saillies spirituelles de Voltaire; suivi des Anecdotes peu connues relatives à ce philosophe et poète célèbre. 1799. http://gallica.bnf.fr/ark:/12148/bpt6k864303.pdf. Accessed 28 Sept. 2017. 
Cousin d'Avallon, Charles-Yves, editor. Bonapartiana, ou Recueil choisi d'anecdotes, de traits sublimes, de bons mots, de saillies, de pensées ingénieuses, de réflexions profondes de Napoléon Bonaparte, avec un aperçu des actions les plus belles et les plus éclatantes de sa vie. Paris, 1833.

Davet, Gerard, and Fabrice Lhomme. “Un président ne devrait pas dire ça . . .": Les secrets d'un quinquennat. Points, 2017.

Dely, Renaud. La Vraie Marine Le Pen: Une bobo chez les fachos. Plon, 2017.

Derrien, Caroline, and Candice Nedelec. Les Macron. Fayard, 2017.

Elgey, Georgette. Toutes fenêtres ouvertes. Fayard, 2017.

Emerson, Ralph Waldo. "History." Essays: First and Second Series. New York, 1883, pp. 7-44.

Fulda, Anne. Emmanuel Macron: Un jeune homme si parfait. Plon, 2017.

Gallo, Max. Bleu Blanc Rouge. XO, 2000.

- Les Chrétiens. Fayard, 2002. 3 vols.

De Gaulle. Robert Laffont, 1998. 4 vols.

. "La France est dans une crise nationale de longue durée." La Croix, 31 Dec. 2010, https://www.la-croix.com/Archives/2010-12-31/Max-Gallo-historien-membre-de-1Academie-francaise.-La-France-traverse-une-crise-nationale-de-longue-duree-_NP_2010-12-31-393201. Accessed 28 Sept. 2017.

- Henri IV. XO, 2016.

- Louis XIV. XO, 2007.

Morts pour la France. Fayard, 2003.

. Napoléon. Robert Laffont, 1997. 4 vols.

. Les Patriotes. Fayard, 2000.

. "Pourquoi je prie." La Vie, 19 July 2017, http://www.lavie.fr/actualite/societe/maxgallo-pourquoi-je-prie-19-07-2017-83756_7.php. Accessed 28 Sept. 2017.

- Richelieu: La foi dans la France. XO, 2015.

. "Il suffit de quelques jours pour que la barbarie rejaillisse." Le Point, 25 Feb. 2009, http://www.lepoint.fr/actualites-politique/2009-02-25/interview-max-gallo-il-suffit-dequelques-jours-pour-que-la/917/0/320453. Accessed 28 Sept. 2017.

- Victor Hugo. XO, 2001. 2 vols.

Gauguin, Paul. Noa Noa. 1901. Bartillat, 2017.

Haziot, David. Gauguin. Fayard, 2017.

Lewis, C. S. Surprised by Joy: The Shape of My Early Life. Harcourt, Brace \& World, 1955.

Macron, Emmanuel. Révolution. XO, 2016.

Macron, Emmanuel, and Eric Fottorino. Macron par Macron. Éditions de l'Aube, 2017.

Métivier, Francis. Mythologie des Présidentiables. Pygmalion, 2017.

Mitterrand, François. Journal pour Anne: 1964-1970. Gallimard, 2016.

- Lettres à Anne: 1962-1995. Gallimard, 2016.

Nora, Pierre. Essais d'égo-histoire. Gallimard, 1987.

Nye, David E. The Invented Self: An Anti-biography, from the Documents of Thomas A. Edison. Odense UP, 1983. 
Peters, Catherine. "Secondary Lives: Biography in Context." The Art of Literary Biography, edited by John Batchelor, Clarendon Press, 1995, pp. 43-56.

Saint Bris, Gonzague. Aristocrates Rebelles. Éditions des Arènes, 2017.

-. Au paradis avec Michael Jackson. Presses de la Cité, 2010.

Sainte-Beuve, Charles-Augustin. "La Littérature industrielle." 1839. https://fr.wikisource. org/wiki/La_Littérature_industrielle. Accessed 28 Sept. 2017.

Symons, A. J. A. The Quest for Corvo: An Experiment in Biography. 1934. Penguin, 1950. 